\title{
MRSA at patient admission: the right question to identify the colonized patient
}

\author{
A Bispo*, C Palos \\ From 3rd International Conference on Prevention and Infection Control (ICPIC 2015) \\ Geneva, Switzerland. 16-19 June 2015
}

\section{Introduction}

Portugal has one of the highest MRSA infection and colonization rates in Europe, so it becomes critical to identify MRSA colonized patients at hospital admission on the Emergency Room (ER), before placement into wards, preventing the mixing of colonized patients with non-colonized ones. Infection Control and Antibiotics Committee (ICAC) developed an Electronic Epidemiological Query at Admission (EEQA) to be answered at patient admission. One of the questions targets MRSA colonization risk.

\section{Objectives}

The objective of our study was to identify the positive predictive value (PPV) of the question that targets the MRSA high risk patient:Hospitalization or long term care admission for at least 3 days in the last 3 months, or tracheostomy?

\section{Methods}

With the approval of the Clinical Board, the ICAC defined as mandatorily the fulfillment of EEQA to all patients at admission. A positive answer to this question triggers automatically (and without the doctors approval or intent) nasal and perianal screening swabs for MRSA. Infection Control nurse activates pre-emptive contact isolation precautions immediately. Swab results are known after $48 \mathrm{~h}$ and then precautions can be stopped or room isolation is implemented.

\section{Results}

In 2014 we had 13.893 EEQA submitted; from these, 3.523 $(23,36 \%)$ were positive for at least one of the 8 questions. The question that targets MRSA colonized risk patient had a positive answer in 3.082 EEQA $(87,4 \%$ of the \footnotetext{
Infection Control and Antibiotics Committee, Hospital Beatriz Ângelo, Loures,
} Portugal
Cite this article as: Bispo and Palos: MRSA at patient admission: the right question to identify the colonized patient. Antimicrobial Resistance and Infection Control 2015 4(Suppl 1):P190.

Submit your next manuscript to BioMed Central and take full advantage of:

- Convenient online submission

- Thorough peer review

- No space constraints or color figure charges

- Immediate publication on acceptance

- Inclusion in PubMed, CAS, Scopus and Google Scholar

- Research which is freely available for redistribution Submit your manuscript at
www.biomedcentral.com/submit C BioMed Central 